\title{
Inventory of Research Inventaire des recherches Relevant to sur l'Enseignement Higher Education in Canada supérieur au Canada
}

\author{
LUCIEN F. MICHAUD, J.F. HOUWING*
}

\section{Introduction}

For the past few years the Association of Universities and Colleges of Canada, in conjunction with the Canadian Society for the Study of Higher Education, has maintained an inventory of on-going research relevant to higher education in Canada. The project was designed to be a complement to the bibliography under the direction of Professor R.S. Harris of the Higher Education Group, University of Toronto. The inventory has attempted to focus on on-going research although it has occasionally included recently completed research.

With this issue of Stoa-The Canadian Journal of Higher Education a new approach has been taken in order to better serve the users. Beginning in 1974 the questionnaire will be administered once a year. The entire returns will be published in the two or three following issues of Stoa. Hence the increase in this section of the journal. Of the six sections indicated below, the first three $(A, B, C)$ will be published in this issue, the other three will appear in the fall 1974 issue.

\section{Introduction}

Depuis quelques années, l'AUCC en collaboration avec la Société canadienne pour l'étude de l'enseignement supérieur, dresse l'inventaire des recherches en cours sur l'enseignement supérieur au Canada. Ce travail vise à apporter un complément à la bibliographie établie sous la direction du professeur Harris. L'inventaire se concentre sur les recherches en cours bien que de temps à autre il ait porté sur des recherches terminées récemment.

Dans le présent numéro de Stoa-la revue canadienne d'enseignement supérieur, on procède d'une nouvelle façon afin de mieux servir les usagers. A partir de 1974, le questionnaire sera administré une fois par année. Toutes les réponses seront publiées dans les deux ou trois numéros suivants de Stoa. La présente section du journal sera donc plus vaste. Des six rubriques mentionnées ci-dessous, les trois premières $(A, B, C)$ sont publiées dans la présente livraison alors que les trois autres paraitront dans la livraison d'automne 1974.

* Lucien F. Michaud, directeur adjoint, A.U.C.C., J.F. Houwing, Research Officer, A.U.C.C. 
Researchers should be aware that it is difficult to get information on on-going or recently completed research which is being done in the federal and provincial governments and their agencies. Most research projects which the governments undertake and which deal with higher education are for internal use. Though a few projects may be published, many of them, if not the majority, never see the light of day. Designed as in-house projects this type of research is prepared for a minister, the cabinet or a special committee.

In the same line of inaccessible research could be classified a number of projects being done by the offices of institutional research or some other administrative unit, or committee within a university. Such projects are usually destined to a board, to a senate, to a special committee or to a senior officer of the university or college. They seldom are published or distributed beyond the campus of the institution.

The readers of this section of Stoa will thus understand that there are many gaps in the inventory and that it is virtually impossible to uncover a number of research projects relating to higher education.

The inventory divides the 171 included projects into six sections; their headings and some of the subjects included in each are:

A General (organizations and structures; research; history; philosophy; objectives; Canadian studies; pedagogical services; general bibliographies)

B Administration, Finance and Manpower (costs; planning; information systems; models; enrolment and other pro-
Les chercheurs doivent de plus savoir qu'il est difficile d'obtenir des renseignements sur les recherches en cours au sein des gouvernements fédéral et provinciaux et de leurs organismes. La plupart de ces études portant sur l'enseignement supérieur sont effectuées en vue d'être utilisées à l'intérieur des gouvernements. Bien qu'il arrive que des études soient publiées, bon nombre d'entre elles, sinon la majorité, ne sont jamais mis au jour. Conçues comme recherches-maison, elles sont faites pour un ministre, le Cabinet ou un comité spécial.

Il en est ainsi de certaines études effectuées par des bureaux de recherche: institutionnelle, par d'autres unités administratives ou des comités d'université. Ces recherches sont faites habituellement pour un conseil, un sénat, un comité spécial ou un administrateur supérieur d'un collège ou d'une université. Elles sont rarement publiées ou distribuées à l'extérieur de l'établissement d'enseignement.

Par conséquent, les lecteurs de la présente section de Stoa se rendront compte que l'inventaire comporte de nombreuses lacunes et qu'il est presque impossible de dénicher certaines études se rapportant à l'enseignement supérieur.

L'inventaire répartit les 171 projets de recherches en six sections; voici les titres des sections et quelques-uns des sujets:

A Généralités (organisations et structures; recherches; histoire; philosophie; objectifs; études canadiennes; services pédagogiques; bibliographies générales)

B Administration, finances et maind'oeuvre (coûts; planifications; systèmes d'information; modèles; prévisions des inscriptions et autres; main-d'oeuvre; em- 
jections; manpower; employment of graduates; statistics; governance; transportation)

C Curriculum and Teaching (evaluation; teaching effectiveness, techniques and aids; grading; learning modes)

D Academic and Non-Academic Staff (classification; characteristics; employment conditions)

E Students (characteristics; socio-economic background; behaviour; educational plans; accessibility; admission; performance; assessment; grades; attrition; financial aid; athletics; housing; drugs; special types of student)

$\mathrm{F}$ Extension and Contmuing Education (adult learning; curriculum; off-campus instruction)

At the end of each section, the reader will find a number of cross-references to entries in other sections, which also bear on the subject of the section consulted.

In addition to a reference number, the projects are presented as follows:

a) the title;

b) a brief description;

c) the (approximate) date of completion;

d) the name and address of the investigator(s), from whom further details can be obtained;

e) if further details should be obtained from another source, this is indicated under this item.

The inventory concludes with an index of the researchers whose work is included. ploi des diplômés; statistiques; administration; transport)

C Programmes d'études et enseignement (évaluation; efficacité, techniques et aides de l'enseignement; notation; modes d'apprentissage)

D Personnel enseignant et non enseignant (classement; caractéristiques; conditions d'emploi)

E Etudiants (caractéristiques; antécédents socio-économiques; comportement; projets d'études et de carrières; accessibilité; admission; résultats; appréciation; notes; défections; aide financière; sports; logement; drogues; types spéciaux d'étudiants)

F Education permanente (éducation des adultes; programmes d'études; enseignement à l'extérieur du campus)

A la fin de chaque section, le lecteur trouvera des renvois aux notices d'autres sections qui traitent aussi du sujet de la section consultée.

En plus d'un numéro de renvoi, les projets comprennent les renseignements suivants:

a) le titre;

b) une brève description;

c) la date (approximative) de la fin des travaux;

d) le nom et l'adresse du (des) chercheur(s) de qui on peut obtenir d'autres détails;

e) si d'autres détails devraient être obtenus d'une autre source, cela est indiqué dans cet article.

A la fin est dressé un index des chercheurs dont le travail est mentionné dans l'inventaire. 


\section{A General/Généralités}

Al a) University cooperation and coordination in the Maritime Provinces b) Overview of university cooperative and coordinative agreements within and among the three Maritime Provinces with some thoughts for the future c) May 1973 d) John R. Cameron, 5 Kingston Crescent, Dartmouth, N.S.

A2 a) History of universities in Nova Scotia b) Development of the universities as related to the social and religious life of the province c) In progress d) John R. Cameron, 5 Kingston Crescent, Dartmouth, N.S.

A3 a) Sociological origins of the community college system of Alberta b) Analy sis of the growth of the structure and the changing functions of the colleges, 1957-1973 c) June $1974 \mathrm{~d}$ ) Gordon Campbell, Fac. of Educ. University of Lethbridge.

A4 a) Vancouver urban futures project b) While the primary purpose is to delineate social issues and attitudes toward urban living among residents of the Greater Vancouver Regional District, characterization can be made of those respondents ( $1 / 2 \%$ of all GVRD households) who have achieved various levels of education or other post secondary training. In particular, the effects of such post secondary school experience on income, housing, leisure time activities, urban attitudes and voting behaviour are at hand. Numerous other relationships will be available in the Data Library Listing at UBC c) Nov. 1973 d) J.B. Collins and W.G. Hardwick, University of British Columbia.

A5 a) Prospectives in higher education b) Analysis of current planning assumptions and methods, description of political and social context for higher education in Quebec. Synthesis of available technology with new, explicit assumptions proposed. Educational planning has to deal more sensitively with interaction of the university with society: more services required: more political sophistication required of universities if they are to remain autonomous. Planning has to evolve into a process of comprehensive design c) Sept. 1973 d) Conférence des recteurs et des principaux des Universités du Québec, 6600 Chemin de la Côte des Neiges, suite 300, Montréal 249, Qué.

A6 a) University research in Quebec: current issues and priorities b) Description of the activities, mandate and recommendations of the CRPUQ's Research Committee; summary of some politics and orientations in university research; priorities for the future c) Jan. 1973 d) Conférence des recteurs et des principaux des Universités du Québec, 6600 Chemin de la Côte des Neiges, suite 300, Montréal 249, Qué.

A7 a) College goals study b) Development of consensus among college constituents as to the goals of the college d) Dan Cornish, Red Deer College, Red Deer, Alta.

A8 a) The influence of the Carnegie endowments on the development of higher education in Canada $1905-1945 \mathrm{~b})$ To study the practices, policies, and procedures with which the endowments aided the cause of higher education and learning. Doctoral thesis University of Toronto/OISE c) April 1975 d) Warren F. Crouse, 48 Maxwell Ave. Apt. 302, Toronto, Ont.

A9 a) The philosophical roots of Egerton Ryerson's idea of education as elaborated in the writings preceding and including the Report of 1846 b) To determine the philosophical sources of Ryerson's educational thought. Also an indirect attempt to verify Ryerson's own claim that in his socio-political thinking he was most influenced by such thinkers as John Locke, William Paley and William Blackstone. Ph.D. thesis University of Toronto/OISE c) Spring 1975 d) Albert Fiorino, 580 Bedford Park Ave., Toronto, Ont.

A10 a) A typology of university education development centres b) In rapidly increasing numbers, universities around the world are creating pedagogical service units in support of effective instruction. The centres take various forms from pure research institutes studying learning processes to "hot line" consulting services on teaching problems. The purpose of the report is to describe the range of types of centres being formed together with the characteristics that make them appropriate to particular kinds of institutions and circumstances c) 1974 d) George L. Geis and Bruce M. Shore, Centre for Learning and Development, McGill University.

A1 1 a) Canadian studies and Canadian universities b) Exploratory study designed to determine 
what concept of "Canadian identity" university department heads and faculty in Ontario hold and whether they see the university as having a responsibility in helping to arrive at and articulate a definition c) June 1974 d) E.B. Harvey, D.E. Jacobs and J.R. Kidd, OISE.

A12 a) Educational policies and the distribution of the post-secondary education industry in Ontario b) The study will produce a description of the distribution of the post-secondary education industry across Ontario. It will estimate the effects of policy behavior in the past decade upon the distribution of population, industry, employment, and income across municipalities. It will then examine the complementarities of expenditure policies of separate public agencies in terms of identified provincial objectives regarding the distribution of wealth, industry, income, and population. This study will emphasize the proposing parties' import-export model of the economic effects of a university or college upon local economies c) June 1973 d) J. Holland and S. Quazi, OISE.

A13 a) Concept of the University of Alberta as seen by students and staff b) A study of eight dimensions of the campus environment by means of a questionnaire surveying a random sample of the student body, academic staff and non-academic staff. Aspects investigated included: professor-student contact, teaching and research, administration, liberalness, specific program or discipline, national standing, characteristics of the student body, and facilities and student services. The aim in general was to describe the campus community as perceived by all constituent groups c) March $1973 \mathrm{~d}$ ) $\mathrm{M}$. Holland, Office of Institutional Research and Planning, University of Alberta.

A14 a) Determining needs and delivery systems for a community college service region b) Feasibility study for the Saskatchewan and Alberta governments to determine educational needs and appropriate delivery systems for a community college service region in Eastern Alberta and Western Saskatchewan c) Sept. 1974 d) E.J. Ingram, A. Konrad, J. Small and G. Kelsey, Dept. of Educ. Admin., University of Alberta.

A15 a) Introducing change in college system b) Collaborative activity between the Dept. of Educ. Admin., University of Alberta and the Manitoba College System to introduce innovations into the system c) March 1975 d) E.J. Ingram and R.G. McIntosh, Dept. of Educ. Admin., University of Alberta. A16 a) A history of McMaster University b) Two volumes: the first covering origins to 1928 when a campaign was launched to move the university from Toronto to Hamilton, the second the period 1928 to 1957 when it became a non-denominational institution c) Vol I 1974, Vol II in progress d) Charles M. Johnston, Dept. of History, McMaster University.

A17 a) Alternative university structures-case study on Canada c) June 1973 d) David C. Munroe, 10 Driveway, Ottawa, Ont. e) Division of Higher Education, UNESCO, Paris.

A18 a) Feasibility of modifying the open university concept and techniques for utilization in the Atlantic region of Canada b) Study of the United Kingdom's open university to determine if this model of off-campus education can be utilized for post-secondary and vocational education in the Atlantic. Will include analysis of local population, determination of need, hardware and software inventory and possible construction of a model delivery system c) Jan. 1974 d) Open University Study Committec, Chairman D. Owen Carrigan, Saint Mary's University.

A19 a) A case study of citizen participation: the involvement of adult educators with provincial governments in developing a community college system for Saskatchewan b) Study of the participation of adult educators and other interested persons in the development of community colleges in Saskatchewan, 1969-1972. Information was obtained concerning the importance of citizen participation and the role of citizens in decision making. Satisfaction with the decision process was related to occupational group, sex, affiliation with an adult education voluntary association, service on a government committee, interest in community college development and attitudes toward citizen participation c) May 1973 d) Elizabeth F. Pepper, 842 University Drive, Saskatoon, Sask.

A20 a) Higher education in Alberta: conceptualization and analysis b) Conceptual overview of the relationship between the institutions of higher education in Alberta (particularly the University of Alberta) and the Department of Advanced Education, providing a framework within which these relationships can be developed. The report contains applied concepts, based on the author's own interpretation of the existing situation, and attempts to present data on the relative role of the various consti- 
tuencies involved in government-higher education relationships c) July 1973 d) Wm. A. Preshing, Office of Institutional Research and Planning, University of Alberta.

A21 a) Royal Commission on Education, Public Services and Provincial-Municipal Relations b) Examination of education and municipal government in Nova Scotia, including universities c) 1974 d) Royal Commission on Education, Public Services and Provincial-Municipal Relations, 1226 Le Marchant St., Halifax, N.S.

A22 a) Royal Commission to Examine Post-Secondary Educational Needs in the Kootenay Region of the Province b) To examine post-secondary educational needs and the roles and opportunities of Selkirk College and Notre Dame University in meeting them; to identify within the province unique educational needs which might effectively be met in the Kootenay region c) Ongoing d) Royal Commission to Examine Post-Secondary Education Needs in the Kootenay Region, Executive Secretary J. Ellis, Fac. of Educ., Simon Fraser University.

A23 a) Bibliographie sur l'enseignement universitaire b) Bibliographie annotée des volumes au 15 août 1972 disponibles dans les différentes bibliothèques de l'Université Laval et portant sur divers aspects de la pédagogie universitaire; 341 pages c) mars 1973 d) Henri Saint-Pierre et Richard Giroux, Service de pédagogie universitaire, Université Laval.

A24 a) Agencies for higher education in Ontario b) In a 1973 symposium, the organization and roles of key agencies were outlined.by their chief officer. To these outlines has been added an overview by the editor. Agencies included are: Council of Regents and Committee of Presidents of Colleges of Applied Arts and Technology, Committee on University Affairs, Council of Ontario Universities, Ontario Confederation of University Faculty Associations, Ministry of Colleges and Universities and Commission on Post-Secondary Education in Ontario c) 1974 d) Edward F. Sheffield, Editor, University of Toronto.

A25 a) Directory of pedagogical services in Canadian colleges and universities b) A survey to seek information about formal institutional support for teaching, form individuals and committees to centres (excluding purely audio-visual centres) c) Early 1974 d) Bruce M. Shore and Janet G. Donald, Centre for Learning and Development, McGill University.

A26 a) Canadian universities and the Canadian identity b) Historical and contemporary analysis of the effects of American influence on Canadian university development and the relationship between this phenomenon and the development of a Canadian identity c) Nov. 1973 d) Robert M. Stamp, Fac. of Educ., University of Calgary.

A27 a) Historical study of the new universities of the Commonwealth (provisional title) b) A group of the delegates to the 1973 Commonwealth Universities Congress agreed that it is important to encourage the systematic preservation of archival and oral history records of the "new universities" of the Commonwealth, including a number of Canadian universities. The purpose of the project which has not yet been formally organized is to provide for the fullest possible documentation of the history of the universities. R.J.Storr has agreed to take responsibility for any clearing house work which promises to be helpful d) Richard J. Stor, Founders College, York University.

A28 a) Institutional functioning project b) Assessment of student and faculty attitudes towards Red Deer College d) Bill Stuebing, Red Deer College, Red Deer, Alta.

A29 a) Report of the Commission on Canadian Studies b) To study, report and make recommendation upon the state of teaching and research in the various fields of study relating to Canadian universities c) April 1974 d) T.H.B. Symons, Trent University.

A30 a) Archival, bibliographic and critical studies in the history of education with particular reference to Ontario b) Study of archival resources pertaining to education in Ontario, with concentration in this coming year on the completion of guides to research inventories of educational materials of historical value which are in the possession of City Boards of Education, Church archives, national archives, and local historical societies and museums c) June 1974 d) T.J. Wigney, W. Brehaut and H. Troper, OISE.

A31 a) Five year development plan b) Collection of information pertaining to post-secondary edu- 
cational needs in Central Alberta and development of suitable college objectives to respond to these needs d) Gerry Kelly, Red Deer College, Red Deer, Alberta.

Cross-reference / Renvois: see also / voir aussi: C19, C25.

\section{B Administration, Finance and Manpower / Administration, finances et main-d'oeuvre}

B 1 a) Etude sur l'évaluation des frais indirects de la recherche b) L'objectif était de déterminer quels étaient les frais indirects causés par la recherche subventionnée durant 1972-73 à l'Université de Sherbrooke. Il s'agit de coûts d'opérations absorbés à même les budgets de fonctionnement, qui n'auraient pas été encourus théoriquement s'il n'y avait pas eu de recherche. La première partie est un relevé des frais selon les facultés et les services; la deuxième est une analyse statistique des frais et des analyses comparatives; la conclusion couvre deux points: une projection des subventions de recherche pour 1973-74 et l'indentification théorique des frais indirects depuis 1965-66 c) Sept. 1973 d) G. Beaudoin et G. Valence, Bureau de développement institutionnel, Université de Sherbrooke.

B2 a) Investment return for university pension funds b) Comparative performance review of investment results for Canadian university trusteed pension funds on a time-weighted basis and analysis of type of asset holdings c) Spring 1974 d) K. Clements, Canadian Association of University Business Officers, 151 Slater Street, Suite 1103, Ottawa, Ont.

B3 a) Etude sur les cồts, mécanismes et structures de la planification au Québec b) La première partie de l'étude consiste en un questionnaire qui essaiera de mesurer les coûts de la planification universitaire, ses mécanismes, et ses structures; la deuxième partie comparera ses coûts, structures et mécanismes à ceux qui existent en Ontario et aux Etats-Unis; la troisième partie proposera différentes alternatives aux universités en ces domaines c) mars 1974 d) Conférence des recteurs et des principaux des universités du Québec, 6600, chemin de la Côte des Neiges, suite 300, Montréal 249, Qué.

B4 a) Une comparaison des systèmes d'information et de gestion des universités. Caractérisation des salaires des cadres c) 1974 d) Conférence des recteurs et des principaux des universités du Québec, 6600, chemin de la Côte des Neiges, suite 300, Montréal 249, Qué.

B5 a) Models and costs of media systems b) Cost models of audio-visual systems will be developed and principles formulated for effective allocation of resources within such systems. Effects of different types of variables upon costs will be analyzed. The level of service of each type of system per dollar expenditure will be compared in detail c) June 1973 d) M. Gailitis, L.D. McLean, OISE.

B6 a) Study of the use of clinical facilities by nursing students in the province of Manitoba b) Study of the effect on patients, nursing personnel, nursing students and their teachers of the intermittent nature of planned education experience in selected clinical areas in hospitals; to be used in the development of a model to facilitate the use of clinical facilities by nursing students and other learners in the health field c) 1976 d) H.P. Glass, School of Nursing, University of Manitoba.

B7 a) Bibliographie-critique des modèles de prévision des effectifs étudiants au niveau universitaire b) On y critiquc les modèles purement projectifs, les modèles en chaîne de Markov, les modèles Markoviens déterministes et les modèles d'entrée-sortie c) mars 1973 d) Gilles Guérin, Ecole des relations industrielles, Université de Montréal.

B8 a) Prévision des effectifs étudiants dans un secteur d'étude réparti sur plusieurs institutions universitaires b) Etude des techniques de programmation mathématique qui permettent d'intégrer plusieurs critères d'optimisation à l'intérieur d'une même fonction économique. La structuration du système ayant été envisagé au niveau d'un ensemble d'institutions qui doivent satisfaire une certaine population ou qui s'engagent à fournir globalement le main-d'oeuvre instruite requise pour le développement d'une région, voire d'un pays, on tentera de déterminer des structures d'admission satisfaisantes en fonction des trois objectifs: obtention des répartitions de gradués souhaitées; satisfaction des objectifs de développement de chaque institution et satisfaction de la demande étudiante relativement aux choix d'admission c) En cours d) Gilles Guérin, Ecole des relations industrielles, Université de Montréal. 
B9 a) Alternative occupational futures and the social science graduate c) Jan. 1973 d) E.B. Harvey, OISE.

B10 a) Education and employment: expectations and experience b) A report to the Ministry of Colleges and Universities in Ontario c) Jan. 1973 d) E.B. Harvey, OISE.

B1 1 a) Educational systems and the labor market b) During the past three years this study of the changing relationship between education and employment has concentrated particularly on the problems of: predicting manpower needs; exploring alternative forms for education in Canadian society, and alternative occupational futures for graduates of the educational system; and developing data bases useful to policy makers. Now that data collection has been completed, it will focus on identifying, through consultation with government representatives, key data needs for policy formulation and planning and on developing a model for resource allocation in higher education c) June 1974 d) E.B. Harvey, OISE.

B12 a) Educational policies and the geographical distribution of the post-secondary education industry in Ontario b) Study of the impact of provincial post-secondary expenditures upon the distribution of employment and other aspects of economic opportunity across the municipalities of Ontario c) Winter 1973-74 d) J. Holland and S. Quazi, OISE.

B13 a) The selection process of community college trustees in Alberta b) Recently appointed trustees were interviewed in an attempt to clarify the procedures involved in nominating and appointing trustees and to provide an understanding of the selection process and ways to improve upon it c) May 1974 d) Abram G. Konrad, Department of Educational Administration, University of Alberta.

B14 a) A planning model for post-secondary education in West Central Minnesota b) Concerned with planning the efficient development of post-secondary education in a region, attention is focused on allocating public resources among competing curricula and institutions, where the primary concern is on the vocational aspects of higher education. The procedure employed used multi-period linear-programming models which maximize the net social benefits generated by the post-secondary system subject to constraints describing the educational technology available to the region and externally imposed policy decisions c) June 1973 d) Peter J. Kuch, Dept. of Economics, University of Western Ontario.

$\mathrm{B} 15$ a) Factor analysis in the investigation of multidimensional educational problems b) The paper discusses the use of factor analy sis and presents the results of one application. Whereas the manipulation of mass information collected on various aspects of a problem is often too complex for most human minds to grapple with, factor-analy tic techniques enable us to simplify the analysis of data by delineating a few salient response patterns. The data can then be more cffectively analyzed with reference to the reduced dimensionality of the response pattern instead of analyzing them with reference to the original variables c) March 1974 d) Nirmal Mehra, Office of Institutional Research and Planning, University of Alberta.

B16 a) Standardized versus unstandardized techniques of factor analysis in a study of organizational climate b) New arguments are presented comparing the two techniques-the standardized vs. the unstandardized-of factor analysis (or equivalently, the $Q$ vs. $R$ techniques). The paper provides empirical evidence that the two techniques yield factors basically different in nature and consequently, which of the two techniques should appropriately be used in a particular study depends on the objectives of the study c) 1973 d) Nirmal Mehra, Office of Institutional Research and Planning, University of Alberta.

B17 a) Toward a general theory of managerial discretion b) General theoretical model of how decisions relative to output, cost and price are arrived at in institutions of higher education and in nonprofit institutions generally c) 1973 d) Jean-Luc Migué, ENAP, Université du Québec, 31, rue MontCarmel, Québec, Qué.

B 18 a) Interdisciplinary questionnaire on existing manpower and future requirements in laboratory medicine b) Phase 1: to correlate the exact function of medical laboratory scientists with the detail of their formal training. Phase 2: to be planned c) March 1974 d) Robert H. More, Pathology Institute, McGill University. 
B19 a) Enquête sur la relation "formation-emploi" - sortants et diplômés de l'Université de Montréal d) Pierre-Paul Proulx, Centre de recherches en développement économique, Pavillon des sciences sociales, 3150, rue Jean-Brillant, Montréal 101, Qué.

B20 a) La revue générale de la main-d'oeuvre hautement qualifiée du Canada - septembre 1973 d) Pierre-Paul Proulx, Centre de recherches en développement économique, Pavillon des sciences sociales, 3150, rue Jean-Brillant, Montréal 101, Qué.

B21 a) Main-d'oeuvre dans le secteur des communications d) Pierre-Paul Proulx, Centre de recherches en développement économique, Pavillon des sciences sociales, 3150, rue Jean-Brillant, Montréal 101, Qué.

B22 a) Main-d'oeuvre dans le secteur financier d) Pierre-Paul Proulx, Centre de recherches en développement économique, Pavillon des sciences sociales, 3150, rue Jean-Brillant, Montréal 101, Qué B23 a) Physician manpower studies - province of Alberta b) Studies on physician manpower, 1970-74, showing trends of population change and specialty interest. Needs for graduate programs and their size have become apparent c) 1974 d) Richard E. Rossall, 8331 Saskatchewan Drive, Edmonton, Alberta.

B24 a) Survey of university information systems b) Survey of the current state of university information systems to assess their basic objectives and outputs, to identify the nature and extent of future demands likely to be imposed on such systems and to formulate proposals which outline a plan to advance the capability of present systems in response to anticipated demands c) Nov. $1973 \mathrm{~d}$ ) Bernard S. Sheehan, Office of Institutional Research, University of Calgary.

B25 a) Limitations of simulation modelling as an aid in university management d) Bernard $\mathrm{S}$. Sheehan, Office of Institutional Research, University of Calgary.

B26 a) A summary, analysis and modification of the Getzels-Guba social process theory of educational administration b) After an in-depth analysis, the thesis uncovered four problem areas which the Getzels-Guba theory inadequately dealt with. The suggested modification overcomes these deficiencies and presents a more unified and coherent theory of educational administration c) Aug. 1973 d) Richard L. Toth, Taymouth, N.B.

B27 a) University academic staff cost models b) To study the feasibility of determining future annual instructional costs for Ontario university academic staff members. The procedure used involves developing two sub-models-the manpower and salary sub-models-which provide needed insight into the dynamics of the growth of instructional costs c) June 1974 d) G.S. Tracz, OISE.

B28 a) Qualified manpower in Ontario - supply/demand relations b) Three-part study which: forecasts to 1985 the expected level of stocks of manpower in occupations covered by the Canadian census classification "Professional, Technical and Skilled Manpower"; forecasts the losses and secondary gains from such factors as retirement, death and emigration, or upgrading and immigration in order to derive the net demand for skilled personnel to be supplied by educational establishments; and discusses alternative "mixes" of educational programs to train this personnel and probably the costs involved. The first part was published in 1968; the second part is being redrafted in light of 1971 Census returns c) June 1974 d) Cicely Watson, OISE.

B29 a) The University of Alberta cost study 1972-73 b) Allocation of operating costs to programs of study resulting in per costs; shows comparable data for previous three years c) Jan. 1974 d) Deborah Wener, Office of Institutional Research and Planning, University of Alberta.

B30 a) University transportation prediction model b) An examination of the probable future transportation requirements of the University of Alberta. Prediction was made possible by developing the transportation determinants of travel times on relevant modes, bus service and campus parking based on transportation studies of students and staff between 1965-66 and 1970-71. Possible university size by 1981-82 was researched to provide a reasonable basis for prediction work. MSc Thesis c) Sept. 1973 d) Wm. J. Williamson, Office of Institutional Research and Planning, University of Alberta.

B31 a) The University of Alberta transportation to 1981-82: I methodology, II study findings b) 
Two reports based on the author's MSc Thesis on university transportation prediction models c) 1973 d) Wm. J. Williamson, Office of Institutional Research and Planning, University of Alberta.

B32 a) Survey of employment opportunities for 1972 university graduates b) Questionnaires were sent out to a sample of the 1972 graduating class to ascertain the type of employment opportunities experienced. Factors such as relevancy of education, job location and mobility, average grades, salaries, number of job offers, etc. were examined. Selected comments expressing problems encountered or concerns felt by the graduates were included in the report c) July 1973 d) George N.S. Zaharia, Office of Institutional Research and Planning, University of Alberta.

B33 a) Projected potential labour force entrants from the Canadian educational systems, 1971 to 1985 b) Projections of enrolments at all levels, particularly at the post-secondary level of non-university courses by duration, and university courses by level of degree sought. Comparable projections of graduates by level, type of degree, diploma or certificates. Main objective: projection of leavers of the educational systems by educational attainment, especially at the post-secondary level c) Early 1974 (without methodology Nov. 1973) d) Z.E. Zsigmond and E. Rechnitzer, Statistics Canada, Ottawa, Ont.

B34 a) Role of the community college president in Ontario b) Research into whether and to what extent the president is seen by himself, the board of governors and the faculty as an educational leader or an institutional manager c) Aug. 1974 d) Tony Powell, Sault CAAT, Sault Ste. Marie, Ont.

B35 a) A selected compendium of recent highly qualified manpower reports b) An annotated listing of about 140 selected reports or surveys which have been carried out within the last five years c) Jan. 1974 d) V. Sonnenfeld, C. Lakaski and B. Cardillo e) The Library, Ministry of State for Science and Technology, Ottawa, Ont.

\section{Curriculum and Teaching / Programmes d'études et enseignement}

C1 a) UVic-CPS correctional education program b) The University of Victoria provides correctional education programs at Penitentiary and Matsqui Institution. About 140 inmates and 40 staff have taken upgrading sessions in basic skills to write grade 12 equivalency tests. In 1973, 112 students were enrolled in four first-year university courses. Four full-time instructors supervised by university professors, operate "schools" within each institution. Broadly conceived, the program provides a basis for further education, but the major objective is rehabilitation. Throughout the program there is a conscious attempt to change attitudes and to improve the level of moral development by discussion of social, political, and ethical issues c) April 1974 (planned on continuing basis) d) J. Douglas Ayers, Fac. of Educ., University of Victoria.

$\mathrm{C} 2$ a) Contrôle d'une expérience de formation des maitres à l'élémentaire b) Evaluation d'un programme expérimental impliquant 115 étudiants-maîtres et durant de 1968 à 1971. L'évaluation fut faite en fonction du degré d'atteinte des objectifs du programme par les ex-étudiants-maîtres une fois rendus dans la pratique de l'enseignement. Ces objectifs ayant été traduits en effets escomptés observables, quatre questionnaires d'attitudes et quatre grilles d'analyse du comportement en classe furent soumises aux diplômés de ce programme ainsi qu'aux sujets d'un groupe-témoin. On croit que les objectifs "attitudinaux" ont été assez bien atteints, mais que les objectifs "comportementaux" ne l'ont pas été d'une manière aussi évidente. Une discussion des résultats termine ce rapport de 568 pages c) juin 1973 d) Antoine Baby, Thérèse Laferrière, Mireille Levesque-Michaud, et Claire Turcotte, Fac. des Sciences de l'éduc., Université Laval.

C3 a) An educational program for nurse practitioners b) Development of an educational program providing additional knowledge, skills, and experience required by nurses in isolated/underserviced areas and development of a model of experience and staff on which to build future educational programs for nurses in primary health care c) March 1975 d) H.W. Bain, Fac. of Medicine and M.C. Cahoon, Fac. of Nursing, University of Toronto.

$\mathrm{C} 4$ a) Evaluation of the MA program in community development at the University of Alberta b) Program assessment based on interviews with representatives from government offices and other 
community development agencies in Alberta c) Dec. 1973 d) Sharon Batt, Office of Institutional Research and Planning, University of Alberta.

$\mathrm{C} 5$ a) Evaluation of the arts one program at the University of British Columbia b) Evaluative description based on interviews with instructors, observation of classes, and comparisons with literature on other experimental arts programs c) Feb. 1974 d) Sharon Batt, Office of Institutional Research and Planning, University of Alberta.

C6 a) L'évaluation du système coopératif b) L'objectif est de porter un jugement documenté sur le système coopératif tel qu'appliqué à certains programmes de Sherbrooke quant aux plans pédagogique et financier, de proposer des améliorations face aux manques possibles du système, et d'établir les critères à utiliser dans l'implantation de nouveaux programmes coopératifs. La méthodologie consistera essentiellement à comparer les étudiants "coopératifs" de Sherbrooke avec leurs semblables des autres universités québécoises par rapport à des critères définis, pour tenter d'isoler l'impact différentiel du système coopératif c) juin 1974 d) Bureau de développement institutionnel, Université de Sherbrooke.

C7 a) Mathematics in Canada b) To study the role of the mathematical sciences in education, science, government and industry, a questionnaire is sent to those who obtained a degree from a Canadian university in mathematics, statistics or computer science in certain selected years. In addition to factual information, the questionnaire will elicit opinions on the strengths and weaknesses of university mathematics education c) June 1974 d) A.J. Coleman and G.D.J. Edwards, Science Council of Canada, 150 Kent Street, Ottawa, Ont.

C8 a) La planification des curriculum c) 1974 d) Conférence des recteurs et des principaux des universités du Québec, 6600 Chemin de la Côte des Neiges, Suite 300, Montréal 249, Qué.

C9 a) Les consortiums et l'innovation curriculaire c) 1974 d) Conférence des recteurs et des principaux des universités du Québec, 6600 Chemin de la Côte des Neiges, Suite 300, Montréal 249 , Qué.

$\mathrm{C10}$ a) Factors in learning first year university economics b) Concerned with: identifying the factors contributing to performance in the first year economics course; retention of economic principles over a five year period; and testing whether students at the end of this period possess a significantly different amount of economic knowledge than those who did not take an economics course. A standardized multiple choice test has been developed to measure economic knowledge c) Summer 1976 d) R.W. Crowley, Ministry of State for Urban Affairs and D.A. Wilton, Statistics Canada, Ottawa, Ont. C11 a) The applications of audio-conferencing in university teaching and administration b) The University of Quebec consists of a network of campuses and institutes. Using equipment located within the university conference calls involving up to seven different localities can be set up. This system is used routinely for the administration of the university and the current project aims to develop its use for teaching purposes c) April 1974 d) John S. Daniel, P. Simard and J.O. Fortier, Université du Québec, Ste-Foy, Québec 10, Qué.

$\mathrm{C} 12$ a) Programmed instruction in elementary building construction "Construction 1 " b) Nonlinear, self-teaching book designed to cover the elements and principles of small scale building. Used in conjunction with prepared $\mathrm{A} / \mathrm{V}$ presentation, experiments and assignments, permits students to learn at their own pace and to retain more knowledge than is usual in conventional methods of instruction. Tutorials conducted as required. Permits large classes to be dealt with on informal basis. Currently in experimental use c) Revised edition Sept. 1974 d) F.J. Eppell, Nova Scotia Technical College.

C13 a) Evidence for effective teaching b) A committee of the Canadian Association of University Teachers is developing a guide to selected indices of effective teaching in higher education in order to describe as wide a variety as possible of alternatives of signs of good teaching, to suggest ways of collecting this information and the most appropriate uses of each. Primary emphasis is on evidence collected by individual instructors for their own use in improving instruction c) Winter 1974-75 d) S.F. Foster, C. Knapper, G.G. Nadeau, B.M. Shore and V.W. Sim, Secretary, CAUT, 66 Lisgar St., Ottawa, Ont.

$\mathrm{C} 14$ a) Ontario remedial mathematics project $\mathrm{b}$ ) To foster the institution of remedial mathematics 
instruction systems at universities in Ontario. Includes preparation of diagnostic tests and exercise sets and cumulation of evaluative bibliography of self-instructional materials, in English and French. Mailing list privileges available free to Ontario university faculty c) 1975 or later d) Dr. Alan J. Gold, Dept. of Mathematics, University of Windsor.

C15 a) Computer assisted instructor (spelling) b) To improve spelling skills c) Jon Thorhallson, Red Deer College, Red Deer, Alberta.

$\mathrm{C} 16$ a) University educational program for family practice nurses (nurse practitioners) b) Program to provide post-basic continuing education to nurses who will function in primary care as physician associates. Preference is given to nurses residing in remote, medically underserviced areas and to those who will function as a role model in provinces where such programs are not now established c) March 1975 d) Dorothy J. Kergin, School of Nursing and Walter O. Spitzer, Dept. of Clinical Epidemiology and Biostatistics, McMaster University.

$\mathrm{C17}$ a) A comparative study of efforts to improve teaching effectiveness in universities b) Survey of efforts to improve university teaching standards, especially through the use of advisory centres and training programmes for faculty and graduate students, in Canada, parts of the U.S.A., the United Kingdom, Australia, New Zealand and selected countries in Northern Europe c) Aug. 1974 d) Christopher K. Knapper, Psychology Dept., University of Saskatchewan, Regina, Sask.

C18 a) Les séminaires b) Monographie sur la méthode d'enseignement: les séminaires comme groupe de discussion c) avril 1974 d) Mariel Leclerc, Faculté des Sciences de l'éduc., Université Laval.

C19 a) An historical introduction to the teaching of international law in Canada b) Brief factual account and some evaluation of the development of teaching public international law in universities, French as well as English speaking, from the mid 19 th century to 1970 e) Nov. 1974 d) R. St. John Macdonald, Fac, of Law, Dalhousie University.

$\mathrm{C} 20$ a) High level language for video digital processor b) Research into establishing and translation of visual matrixes (film shots, still pictures, tv sequences) into digital form, usable as guidance of artist, when in use with digital processed feedback on graphic display c) 1974 d) M.F. Malik, and E. Cerny, Loyola College, 7141 Sherbrooke St.W., Montreal, Qué.

$\mathrm{C} 21$ a) $A$ training and evaluation program for paramedical personnel in Anaesthesia b) Development of a training and evaluation program for graduate nurses working in professional association with physician anaesthetists c) 1974 d) J.W.R. McIntyre, Fac. of Medicine, University of Alberta.

$\mathrm{C} 22$ a) The learning process in small groups b) Different kinds of experimental groups (training groups, psychotherapy groups, case-study groups, seminar groups) are videotaped over a number of sessions (minimum 10, maximum 20). Transcripts are made and interactions coded from videorecordings to various systems of analysis c) 1974 d) John McLeish, Department of Educ. Psychology, University of Alberta.

$\mathrm{C} 23$ a) Student assessment of the intersession program at U.N.B. b) Faculty and student reactions are sought as part of the assessment of an intersession program, introduced in 1972 as a pilot project. The first phase consists of a questionnaire to 575 full and part-time students to determine who attends intersession; why; study behaviour during intersession; and opinions about support services and organizational matters c) March 1974 d) John F. Morris, Extension Dept., University of New Brunswick.

$\mathrm{C} 24$ a) Development of teaching-techniques for the introductory courses in the engineering curriculum b) Development of techniques, demonstrations and motivational arguments for the first courses in engineering: introduction to engineering, graphics, measurements, surveying, statics, dynamics and strength of materials d) Dermot Mulrooney, Engineering Faculty, Saint Mary's University.

$\mathrm{C} 25$ a) Physical education - a study of professional education in Ontario universities b) Historical, interpretive description of traditional and contemporary views of both the idea of the university and professional education undertaken to set the context for an analysis of three schools of physical education as they relate to and perform the functions of a university c) Oct. $1973 \mathrm{~d}$ ) Maureen O'Bryan, School of Phys. and Health Educ., University of Toronto.

C26 a) A computer-based systematic approach to diagnosis and instruction for mathematics skills 
b) The project has created an extensive pool of hierarchically related materials for diagnostic testing and instruction of pre-requisite core-skills in mathematics for students entering colleges of applied arts and technology. The computer facility specifies and corrects the students' remedial needs in mathematics. Field trials to date indicate that a great many more students pass the CAI course than pass with conventional instruction, and the number of contact hours is approximately one-half. Work will involve the implementation of a production system to operate independently from the development agency, along with continued field trials and evaluation. Extensions will be made to the existing course materials to adapt them for manpower retraining (high school) students. Course development will begin in areas of business mathematics and technology mathematics at the year 1 level of CAAT instruction c) June 1974 d) W. Olivier and G. Scott, OISE.

C27 a) Report to the GFC Committee to Investigate Teaching on the use of the pass/fail grades during 1971-72 b) A matching of students in classes with pass/fail grading with students who were not part of the pass/fail study to test whether students from rural areas have lower matriculation scores than those from urban communities; whether males from rural areas will elect pass/fail more often than females from rural areas or males and females from urban areas; and whether students who elected pass/fail will do poorer or better c) $1973 \mathrm{~d}$ ) David Otto, Office of Institutional Research and Planning, University of Alberta.

$\mathrm{C} 28$ a) The teaching effectiveness of an alternative teaching facility b) An experimental section of an English course was compared to a conventional one. No significant differences were found in grades earned by the students in the two groups. However, participation, disagreement with the instructor, and openness to criticism by peers were more in evidence in the experimental class than the controlled one c) 1973 d) David Otto, Office of Institutional Research, University of Alberta and Peter Horowitz, Dept. of English, University of Saskatchewan, Regina, Sask.

C29 a) L'enseignement par modules-guide de réalisation b) Concernant une formule d'enseignement qui favorise l'apprentissage individualisé, le rapport de 15 pages porte sur les conditions requises pour le succès d'un projet pédagogique impliquant la technologie éducative et sur les étapes d'élaboration de modules d'enseignement c) sept. 1973 d) Jacques Parent, Service de pédagogie universitaire, Université Laval.

C30 a) L'enseignement par modules, au niveau de l'enseignement supérieur b) Traduction de la lère partie de l'article Modular Instruction in Higher Education: A Review, par B. et M. Goldschmid, McGill University, janvier 1972. L'article de 11 pages a pour but de faire une revue des principes, de la mise en place, de l'administration, des dimensions, des problèmes et de la recherche se rapportant à l'enseignement par modules c) Oct. 1973 d) Jacques Parent et Mariel Leclerc, Service de pédagogie universitaire, Université Laval.

C31 a) Contributions de la psychologie cognitive et phenomenologique à l'enseignement universitaire b) Portant sur les conditions d'apprentissage, le modèle propose de considérer: l'investissement de soi dans l'expérience (motivation et implication émotive); le traitement de l'expérience (modes de pensée: créative, conceptuelle, évaluative, implicative); et l'intégration de l'expérience (signification logique et psychologique de la situation d'apprentissage) d) Denis Pelletier, Fac. des Sciences de l'éducation, Université Laval.

C32 a) Evaluation des cours à l'Université Laval b) Au cours de 1973-74, on identifie les problèmes que comportent les types d'évaluation utilisés et leur utilité. La deuxième phase (1974-75) consiste: à mettre au point un système qui permettra au professeur de fixer à l'avance des critères qui lui permettront par la suite d'évaluer plus objectivement les connaissances de ses étudiants; de promouvoir l'évaluation de type formatif (formative évaluation) et l'utilisation de tests critères; et à replacer dans un contexte plus limité (d'ordre administratif) l'évaluation cumulative ou terminale (summative evaluation) c) mai 1976 d) Jacques Plante, Henri Saint-Pierre, Marcel Leclerc et Jacques Parent, Service de pédagogie universitaire, Gérard Scallon, Fac. des Sciences de l'éduc., Université Laval. $\mathrm{C} 33$ a) Effective college teaching (interim title) b) Independent of particular subject matter interest, the book will relate to the operations of instruction: new models for evaluation; ways of organizing materials for lectures, seminars, tutorials and laboratory episodes; application of technologies to 
instruction; and subsequent differentiation of teaching roles c) Aug. 1974 d) Leone M. Prock, Fac. of Educ., Simon Fraser University.

C34 a) Assessment of computer assisted learning in an undergraduate (MD) cardiology course b) The use of this program has extended now over 3 years and data is accumulating as student performance and student assessment of this medium c) 1975 d) Richard E. Rossall, 8331 Saskatchewan Dr., Edmonton, Alberta.

C35 a) Recherche d'une pédagogie pour le 17-24 ans (niveaux collégial et universitaire) b) Développement de la théorie de participation en classe et de la rédaction du nouveau rationnel. Thèse de doctorat c) juin 1976 d) Henri Saint-Pierre, Fac. des Sciences de l'éduc., Université Laval.

$\mathrm{C} 36$ a) Role-conflict in the residency programme: a study in postgraduate medical education b) MA thesis c) June 1973 d) Malcolm M.R. Seheult e) OISE library.

C37 a) Teaching in the universities: no one way b) Twenty-three professors, identified by their former students as excellent teachers, present highly personal accounts of their views of teaching and their ways of going about it (19 in English, four in French). In addition to summarizing these accounts, the editor analyzes the responses made by the thousand graduates who commented on professors they remembered as good teachers c) 1974 d) Edward F. Sheffield, Editor, University of Toronto.

C38 a) Characteristics of effective teaching in Canadian universities-an analysis based on the testimony of a thousand graduates b) Details of the analysis included in summary form in "Teaching in the universities: no one way" (see previous entry). The overall pattern of comments made by graduates about professors they remembered as excellent teachers is presented, as are comparisons between professors met under different conditions-in large and small classes, in various fields of study, in anglophone and francophone universities, etc. Also compared are the recollections of recent graduates with those who completed their first degree five and ten years earlier c) 1974 d) Edward F. Sheffield, University of Toronto.

C39 a) Decision-making by the instructor in individualized instruction b) The study examines the information base on which instructors at elementary school, high school, college, undergraduate, and graduate levels base instructional decisions concerning individual students. Also studied are the processes with which this information is applied and the relations to other data obtained from students and school records c) 1975 or 1976 d) Bruce M. Shore, Centre for Learning and Development, McGill University.

$\mathrm{C} 40$ a) Intensive writing workshop b) An intensive brief course in remedial composition for students past the 1st year of university in disciplines outside of English who are, nevertheless, in danger of failing through problems with the mechanics of English. Strategy involves a game-correction technique, using small amounts of money as a motivation, and graduate students (near the subjects in age) as teachers. Reversible tests to be given as diagnostic instruments at the beginning of the experimental course and measurements of progress at the end. The careers of the subjects will be followed for the following years c) June 1974 d) H.F. Smith, Dept. of English, University of Victoria.

$\mathrm{C} 41$ a) The comparative effectiveness of live and videotaped presentations for student achievement b) Research has so far demonstrated that with a difficult concept which can be measured precisely for the cumulative curve, live presentations produce a higher level of student achievement than videotaped presentations of the same material. Further research will attempt to find if there is a type of subject matter for which videotaped presentations will produce a higher level of achievement either immediately or after an interval of several weeks c) June 1974 d) Arthur M. Sullivan and Richard Maddigan, Junior Division, Memorial University.

C42 a) Student and instructor directed approaches to teacher education in elementary science: a comparative analysis b) Students were randomly assigned to two groups for an introductory elementary school science class. In one group student direction, choice and decision-making was maximised, in the other the instructor decided on the activities. The groups were compared on the basis of cognative, attitude, and competency outcomes as well as an interview. The data were analysed using a $2 \times 2$ factorial design. The findings may have implications for individualisation of instruction and student 
independence within courses in higher education c) Late 1974 d) Marvin F. Wideen, Fac. of Educ., McGill University.

C43 a) Innovative developments in teaching labs b) Concerned with ideas that will improve students motivation, increase the professional content of experiments, minimize time spent on work that industry would give to a technician, and develop the students ability to use the lab as a tool for obtaining information to solve engineering problems. Also interested in ways of making better use of space and of cutting capital and operating costs c) Continuing d) J.L. Wighton and Salah ud Din, Fac. of Engineering, University of Saskatchewan, Regina, Sask.

C44 a) Pédagogie universitaire: la méthode du séminaire b) Recherche sur l'enseignement de la sociologie avec des travaux annexes portant sur d'autres disciplines. Etudes de cas. Idée directrice: la pédagogic comme traduction opératoire implicite d'une discipline. Méthodes: observation, entrevues, expérimentation c) sept. 1974 d) Nicole Gagnon, Dépt. de sociologie, Université Laval.

Cross-references/renvois: see also/voir aussi A10, A1 1, A23, A25, B5, B6.

\section{Index of Research Workers / Index des chercheurs}

\begin{tabular}{|c|c|c|c|}
\hline Ayers, J.D. & $\mathrm{Cl}$ & Harvey, E.B. & $\mathrm{A} 11, \mathrm{~B} 9, \mathrm{~B} 10, \mathrm{~B} 11$ \\
\hline Baby, A. & $\mathrm{C} 2$ & Holland, J. & $\mathrm{A} 12, \mathrm{~B} 12$ \\
\hline Bain, H.W. & C3 & Holland, M. & A13 \\
\hline Batt, S. & $\mathrm{C} 4, \mathrm{C} 5$ & Horowitz, P. & $\mathrm{C} 28$ \\
\hline Beaudoin, G. & BI & Ingram, E.J. & $\mathrm{A} 14, \mathrm{~A} 15$ \\
\hline Brehaut, W. & A30 & Johnston, C.M. & A16 \\
\hline Butt, R.L. & $\mathrm{C} 42$ & Kelly, G. & A31 \\
\hline Cahoon, M.C. & C3 & Kelsey, G. & A 14 \\
\hline Cameron, J.R. & $\mathrm{A} 1, \mathrm{~A} 2$ & Kergin, D.J. & $\mathrm{Cl}$ \\
\hline Campbell, G. & A3 & Knapper, C.K. & $\mathrm{C} 13, \mathrm{C} 17$ \\
\hline Cardillo, B. & B35 & Konrad, A.G. & $\mathrm{Al} 14, \mathrm{~B} 1$ \\
\hline $\begin{array}{l}\text { Cerny, E. } \\
\text { Clements, } \mathrm{K} \text {. }\end{array}$ & $\begin{array}{r}\mathrm{C} 20 \\
\mathrm{~B} 2\end{array}$ & Kuch, P.J. & B 14 \\
\hline $\begin{array}{l}\text { Clements, K. } \\
\text { Coleman, A.J. }\end{array}$ & $\begin{array}{l}\mathrm{B} 2 \\
\mathrm{C} 7\end{array}$ & Laferrière, $\mathrm{T}$. & $\mathrm{C}$ \\
\hline $\begin{array}{l}\text { Coleman, A.J. } \\
\text { Collins, J.B. }\end{array}$ & A4 & Lakaski, C. & B3 \\
\hline Cornish, D. & A7 & Leclerc, M. & $\mathrm{C} 18, \mathrm{C} 30, \mathrm{C} 32$ \\
\hline Crouse, W.F. & A8 & Lévesque-Michaud, M. & \\
\hline Crowley, R.W. & $\mathrm{ClO}$ & Macdonald, R. St.J. & C19 \\
\hline Daniel, J.S. & $\mathrm{Cll}$ & Maddigan, R. & $\mathrm{C} 4$ \\
\hline Din, S. ud & $\mathrm{C} 43$ & Malik, M.F. & $\mathrm{C} 2$ \\
\hline Donald, J.G & A25 & McIntosh, R.G. & A 1 \\
\hline Edwards, G.D.J. & C7 & McIntyre, J.W.R. & \\
\hline Eppell, F.J. & $\mathrm{Cl} 2$ & McLean, L.D. & \\
\hline Fiorino, A. & A9 & Mehra, N. & $\mathrm{B} 15, \mathrm{Bl}$ \\
\hline Fortjer, J.O. & Cll 1 & Migué, J.-L. & B l \\
\hline Foster, S.F. & $\mathrm{Cl3}$ & More, R.H. & B 18 \\
\hline Gagnon, N. & C44 & Morris, J.F. & $\mathrm{C} 2$ \\
\hline Gailitis, M. & B5 & Mulrooney, D. & $\mathrm{C} 2$ \\
\hline Geis, G.L. & Al0 & Munroe, D.C. & A 17 \\
\hline Girous, R. & A23 & Nadeau, G.G. & $\mathrm{C} 13$ \\
\hline Glass, H.P. & B6 & O’Bryan, M. & $\mathrm{C} 25$ \\
\hline $\begin{array}{l}\text { Gold, A.J. } \\
\text { Guérin, G. }\end{array}$ & $\begin{array}{r}\mathrm{Cl4} \\
\mathrm{B} \quad \mathrm{B} 8\end{array}$ & Olivier, W. & $\mathrm{C} 2$ \\
\hline Hardwick, W.G. & A4 & Otto, D. & $\mathrm{C} 27, \mathrm{C} 28$ \\
\hline
\end{tabular}


Parent, J.

Pelletier, D.

Pepper, E.F.

Plante, J.

Powell, T.

Preshing, Wm. A.

Prock, L.M.

Proulx, P.-P.

Quazi, S.

Rechnitzet, E.

Rossall, R.E.

Saint-Pierie, $\mathrm{H}$.

Scott, G.

Seheult, M.M.R.

Sheehan, B.S.

Sheffield, E.F.

Shore, B.M.

Sim, V.W.

Simard, P.

Small, J.

Smith, H.F.

Sonnenfeld, V.
C29, C30, C32

C31

A 19

C 32

B34

A 20

C33

$\mathrm{B} 19, \mathrm{~B} 20, \mathrm{~B} 21, \mathrm{~B} 22$

$\mathrm{A} 12, \mathrm{~B} 12$

B33

B23, C34

A 23, C 32, C 35

$\mathrm{C} 26$

C36

B24, B25

A24, C37, C38

A10, A25, C13, C39

C13

C11

A 14

C40

B35
Spitzer, W.O.

C16

Stamp, R.M.

Storr, R.J.

Stuebing, B.

Sullivan, A.M.

Symons, T.H.B.

Thorhallson, J.

Toth, R.L.

Tracz, G.S.

Troper, $\mathrm{H}$.

Turcotte, $\mathrm{C}$.

Valence, $\mathrm{G}$.

Watson, C.

Wener, D.

A26

A 27

A28

C41

A29

C 15

B26

B27

A 30

C2

B1

B28

Wideen, M.F.

B29

Wighton, J.L.

$\mathrm{C} 42$

C43

A 30

Wigney, T.J.

B30, B31

Williamson, Wm. J.

C10

B32

Zaharia, G.N.S.

Zsigmond, Z.E. 